\title{
Strategic Entrepreneurs at Work: The Nature, Discovery, and Exploitation of Entrepreneurial Opportunities
}

\begin{abstract}
What do entrepreneurial opportunities look like? How do firms discover and exploit these opportunities to create value and sustain competitive advantage? This paper reviews the strategic management and entrepreneurship literatures to identify the nature and character of entrepreneurial opportunities and the entrepreneurial strategies that firms employ to seize and commercialize these opportunities. Three emerging schools are identified. The economic school argues that entrepreneurial opportunities exist as a result of the distribution of information about material resources in society. The cultural cognitive school argues that entrepreneurial opportunities exist as a result of environmental ambiguity and the cultural resources available to interpret and define these opportunities. Finally, the sociopolitical school stresses the role of network and political structures in defining entrepreneurial opportunities. We integrate these perspectives to offer a way to improve understanding of the opportunity creation and exploitation process.
\end{abstract}

KEYWORDS: entrepreneurial opportunity, competitive advantage, information distribution, environmental ambiguity, networks.

JEL CLASSIFICATIONS: L26, M13, O32, O33, Z13.

\section{Introduction}

Shane and Venkataraman (2000) have defined entrepreneurship as "the scholarly examination

Final version accepted on 15 November 2006.

Yosem E. Companys

Management Science and Engineering

Stanford University

Stanford, CA, USA

E-mail: companys@stanford.edu

Jeffery S. McMullen

Hankamer School of Business

Baylor University

Waco, TX, 76798-8006, USA

E-mail: Jeffery_McMullen@Baylor.edu of how, by whom, and with what effects opportunities to create future goods and services are discovered, evaluated, and exploited" (218). They go on to suggest that the field should study "the sources of opportunities; the processes of discovery, evaluation, and exploitation of opportunities; and the set of individuals who discover, evaluate, and exploit them" (218). Their concern, however, is not with all market opportunities, but rather "entrepreneurial opportunities," which the authors define as situations that entail the discovery of new means-ends relationships in which new goods, services, raw materials, and organizing methods are introduced to generate economic value (Shane and Venkataraman, 2000; Casson, 2003). Because the development of novel goods and services is often believed to be tied inextricably to wealth creation (Schumpeter, 1934; Kirzner, 1997) and the process of innovation is an important source of competitive advantage (Ahuja and Katila, 2004), the discovery, evaluation, and exploitation of entrepreneurial opportunities is of strategic concern as well (Hitt et al., 2001). As a result, the development of the opportunity construct is critical to the study of strategy and entrepreneurship and has enormous potential to coalesce these fields into a unified conceptual framework.

Researchers in both fields have used the opportunity construct to examine how individual traits, institutional characteristics, and resource configurations influence entrepreneurial performance. For instance, scholars have explored how individuals leverage prior knowledge to discover and exploit entrepreneurial opportunities (Eisenhardt and Schoonhoven, 1990; Shane, 2000) and how entrepreneurs 
formulate and implement entrepreneurial strategies to achieve superior performance (Mosakowski, 1998) and to sustain competitive advantage (Rindova and Kotha, 2001) in highly uncertain and competitive environments. Scholars have also shown how entrepreneurial opportunities (in the form of new technologies) foster the formation of firms (Shane, 2001) and create value through innovation spillovers (Jaffe, 1986). Scholars have even explored the "dark side" of entrepreneurial opportunities, arguing that technological discontinuities (Tushman and Anderson, 1986) and architectural innovations (Henderson and Clark, 1990), enable "alert" firms (Kirzner, 1997) to capitalize on opportunities at the expense of others that remain "trapped" in existing paths or ways of doing things (Christensen and Bower, 1996; Ahuja and Lampert, 2001).

Despite these advances and the importance of entrepreneurial opportunities to strategy and entrepreneurship, there have been surprisingly few recent studies that explore the nature of opportunities - for notable exceptions, please see Casson (2003) and McMullen and Shepherd (2006). Indeed, scholars have yet to develop an integrated theoretical framework that explains the emergence and development of entrepreneurial opportunities. Without such a framework, little can be said about the relationship between opportunity, innovation, and performance and the strategies that are needed to discover and exploit new opportunities. Currently, scholarly understanding of the origins of entrepreneurial opportunities remains limited owing to the fact that most studies have taken opportunities for granted when exploring strategic and entrepreneurial processes. Fortunately, the importance of the opportunity construct to wealth creation has ensured a sizable body of work to draw from in the effort to make implicit assumptions explicit and to enable a framework to emerge from the literature. Should the opportunity construct remain unspecified, however, its implications could be vague and tautological. Consequently, it would seem that scholars need to theorize more about the nature and character of opportunities before they seek further empirical instantiations of the construct.
In this article we conduct a literature review of the strategic management and entrepreneurship literatures to answer two questions: First, what do entrepreneurial opportunities look like? And second, how do firms discover and exploit these opportunities to create value and sustain competitive advantage? Our exploration reveals three distinct, implicitly held views of entrepreneurial opportunity within the literature. Each of these schools conceives of an opportunity as a situation that promises the potential for profit. However, each attributes that situation to different sources of change, and as a result emphasizes different strategies in the discovery and exploitation of entrepreneurial opportunities. Thus, we demonstrate that the strategy chosen to exploit an entrepreneurial opportunity is likely to depend on how entrepreneurial opportunity is conceptualized.

The paper proceeds as follows. In the next section, we draw upon Whetten's (1989) journalistic questions of theory development (i.e., who, what, where, when, why, and how) to provide an organizing framework for the examination of the epistemological evidence, which suggests that the current literature is characterized by three distinct schools of entrepreneurial opportunity. We then introduce a preliminary typology of these schools and use it to identify strategies for opportunity discovery, exploitation, and wealth creation. Finally, we conclude with some possible directions for future research.

\section{The sources and nature of entrepreneurial opportunities}

In his modern classic, Whetten (1989) uses the journalistic questions of who, what, where, when, why, and how to dissect the process of theory development. The What element addresses the question, "Which factors (variables, constructs, concepts) logically should be considered as part of the explanation of the social or individual phenomena of interest?" (Whetten, 1989: 490). The How element concerns how this set of factors is related. Together, the elements of What and How constitute the domain or subject of the theory. The Why element then addresses the "underlying 
psychological, economic, or social dynamics that justify the selection of factors and the proposed causal relationships?"' (Whetten, 1989: 491). Thus, What and How provide description while Why provides explanation. Finally, Whetten argues that the Who, Where, and When elements act as conditions that place limitations on the propositions generated from a theoretical model. He adds, "These temporal and contextual factors set the boundaries of generalizability, and as such constitute the range of the theory" (Whetten, 1989: 492).

Using this framework, we consider the what, where, when, how, why, and who of entrepreneurial action in the effort to develop a typology of entrepreneurial opportunity. Although we would like to start directly with the opportunity construct, closer consideration reveals that the construct only has meaning within the context of the pursuit of some end. Therefore, an entrepreneurial opportunity is more accurately described as an opportunity to engage in entrepreneurial action, in which entrepreneurial denotes a sub-class of some broader category of human action. Because all human action is arguably motivated by profit (Homans, 1964), the adjective entrepreneurial is used to qualify the manner by which this profit is sought - i.e., through the introduction of new goods or services. Consequently, entrepreneurial action, or seeking to profit by introducing new goods or services, constitutes the What element of our theoretical inquiry.

According to this line of argument, opportunities then become the Where and When of entrepreneurial action - i.e., a situation in which one can attempt to profit by creating new goods or services. This is consistent with Shane and Venkataraman (2000) who borrow from Casson (1982) to define entrepreneurial opportunities as objective situations that entail the discovery of new means-ends relationships through which new goods, services, raw materials, and organizing methods can be introduced to produce economic value. In this sense, entrepreneurial opportunities can be differentiated from other profit-oriented, market opportunities that emerge from efficiency gains in the production of existing goods, services, raw materials, and organizing methods. As opposed to entrepre- neurial opportunities, market opportunities result from the optimization of existing, rather than new, means-ends relationships (Kirzner, 1997; Shane and Venkataraman, 2000). As a result, entrepreneurial opportunities represent hitherto unknown ways of doing things (Kirzner, 1973).

Although most scholars have generally agreed with Shane and Venkataraman's conceptualization of entrepreneurial opportunities, they have disagreed on the sources and nature of these opportunities. If one assumes a given set of individuals with stable preferences who are already maximizing their utility according to existing data, then entrepreneurial opportunities, the potential for profit, and the productivity gains that accompany innovation, can only exist if there is a change in situation. Accordingly, we suggest that changes in situation arise as a result of variations in the How, Why, and Who elements of entrepreneurial action and that distinct schools of thought have emerged as a result of emphasizing one of these elements while holding the other two constant by implicit assumption.

The How element refers to changes in data about material resources that, given a particular set of individuals (Who) with stable preferences (Why), impact the production possibilities frontier by enabling new possible solutions to existing problems. This production possibilities frontier, however, is not some objectively determined calculation of an omniscient theorist. Instead, we argue that it is limited by the knowledge of the individuals who are involved in the production and consumption of goods or services that act as solutions to particular problems. Thus, the production possibilities frontier is simply the best known solution to a particular problem at a given point in time. Consequently, knowledge is often conceived of as a stock of objectively meaningful data, or "information," and entrepreneurial opportunities tend to be viewed as objective in nature, existing in the environment awaiting discovery. Scholars who share this view of entrepreneurial opportunity tend to fall within the economic school.

The Why element refers to changes in interpretations of data that, given a particular set of individuals (Who) and data (How), impact the 
production possibilities frontier by transforming the problem that the production function is seeking to solve - i.e., redefining how the problem is understood. Consequently, knowledge is often viewed as understanding, and individuals are thought to be engaged in a perpetual process of sense making. As a result, entrepreneurial opportunities tend to be conceived as subjective in nature, requiring the use of interpretive processes to discover them and to create new social definitions to exploit them. Scholars who share this view of entrepreneurial opportunity tend to fall within the cultural cognitive school.

Finally, the Who element refers to changes in who is interpreting the data. That is, given a particular set of data (How) and preferences (Why), introduction of a new interpreter impacts the production possibilities frontier by changing the stock of data, its meaning, or both. As a result, entrepreneurial opportunities can be conceived as objective or subjective in nature, depending on whether the focus of discussion is on changes in the data or changes in the interpretation of the data that are introduced by the new party. Scholars who share this view of entrepreneurial opportunity tend to fall within the sociopolitical school and argue that opportunities are objective in the sense that they are embedded in existing network structures, but subjective in the sense that their exploitation requires that entrepreneurs behave with considerable political skill to persuade others to commercialize the opportunity.

Therefore, each of these schools, the economic, the cultural cognitive, and the sociopolitical, can be understood in terms of a production function that is currently in use to produce goods and services that act as solutions to problems. The potential for profit requires an entrepreneurial opportunity (i.e., a situation) that enables the introduction of new goods and services by extending the production possibilities frontier. This situation arises from one of three sources: (1) changes in data (information) about material resources, (2) changes in interpretations (preferences), or (3) changes in the interpreter. Different schools of entrepreneurial opportunity have emerged around each of these sources of change.

\subsection{The economic school}

Shane and Venkataraman have argued that entrepreneurial opportunities are "objective phenomena", existing in time and space even though they may not be known to all people at all times (Shane and Venkataraman, 2000). Thus, opportunities exist awaiting alert (or knowledgeable and attuned) individuals to recognize them (Kirzner, 1973). This view has been implicitly incorporated into most studies of strategic entrepreneurship, where the focus has been on how firms systematically discover and exploit opportunities via processes of search, learning, and innovation (Nelson and Winter, 1982; Denrell et al., 2003).

The economic school attributes the existence of entrepreneurial opportunities to the distribution of information regarding material opportunities in society (Arrow, 1962; David and Foray, 2003). It argues that economic actors, on average, are ignorant of many of these opportunities (Kirzner, 1973) and limited in their information of how best to employ resources to discover and exploit them (Shane and Venkataraman, 2000). In such a state of "sheer ignorance" (Kirzner, 1973), individuals and firms must conjecture about the value of potential opportunities and experiment with available resources, capabilities, and information to discover these opportunities. Unfortunately, experimentation is a costly, time consuming search process that entails an opportunity cost, namely, the inability to exploit existing market opportunities (March, 1991). In other words, the strategic actions and commitments that economic actors need to undertake to discover entrepreneurial opportunities preclude other courses of action (Nelson and Winter, 1982). Moreover, given an existing set of resource and time constraints, the limited capacity of boundedly rational actors to process information renders the discovery of a complete set of entrepreneurial opportunities an impossible task (March and Simon, 1958). Even with all the necessary means at hand to discover entrepreneurial opportunities, economic actors would still face the challenge of causal ambiguity (Mosakowski, 1997), which refers to the inability of actors to make sense of the most efficient 
means for achieving a given outcome. Given this uncertainty, the ends themselves become elusive because they are highly variable and uncertain (Scherer et al., 2000).

According to the economic school, entrepreneurial opportunities provide a competitive advantage to the first firm that is able to discover and exploit them (Lieberman and Montgomery, 1988). The competitive advantage is transient, however, because, as information on valuable opportunities becomes available, other firms will develop the resources and capabilities required to exploit these opportunities (Teece et al., 1997; Eisenhardt and Martin, 2000). The process will most likely entail the imitation and replication by competitors of the early mover's competitive advantage (Jacobson, 1992; Roberts and Eisenhardt, 2003). In time, increased competitive activity will erode the value of the opportunity and stabilize the market towards a new competitive equilibrium (Kirzner, 1997).

In short, the economic perspective contends that differences in economic information are fundamental to the existence of entrepreneurial opportunities. Holding all else constant (i.e., What, Where, When, Who, and Why), this perspective attributes competitive advantage to discovering and exploiting new solutions to existing problems made possible as a result of new information about the means of production (How). Thus, new data about material resources is the source of entrepreneurial opportunity, and emphasis is placed on how problems are solved. Concurrently, the Why element is assumed to be constant, meaning that preferences remain stable and problems are not redefined. Moreover, the purpose for acquiring data is assumed to be the same for all market actors, which allows data and information to become synonymous concepts. Finally, the Who element is also held constant by assumption, such that new data is not simply attributed to the involvement of new individuals in the production process.

\subsection{The cultural cognitive school}

In contrast to the economic school, the cultural cognitive school tends to posit that entrepreneurial opportunities are subjective, not objective, phenomena. Opportunities are subjective because they are contingent on the degree of ambiguity in the environment and on the ability of social actors to develop the mental models needed to interpret and define them as opportunities. Proponents of this view suggest that entrepreneurial opportunities exist once they are defined and enacted by individuals and firms (Weick, 1979). The cultural cognitive school is similar to the economic school in that it posits that differences in the distribution of knowledge are the primary source of entrepreneurial opportunities. However, proponents of this view depart sharply from economics in that they consider the distribution of knowledge as culturally grounded in societal systems of meanings and understandings. Thus, entrepreneurial opportunities do not exist objectively waiting to be discovered. Instead, social actors construct them systematically by borrowing and combining cultural schemas and templates to develop new meanings and understandings (Swidler, 1986).

Proponents of the cultural cognitive school contend that the possession of distinctive cultural knowledge is the basis for a sustainable competitive advantage (Rindova and Fombrun, 1999). Under conditions of pluralistic ignorance (Latane and Darley, 1968), an entrepreneur can articulate stories to define the perceived opportunity (Lounsbury and Glynn, 2001), make claims to the opportunity (Rindova and Fombrun, 2001; Santos, 2003), and persuade others of its value (Hargadon and Douglas, 2001). Because opportunities are contingent on prior experience (Eisenhardt and Schoonhoven, 1990; Shane, 2000), social actors will vary in the cultural knowledge and experience they have to enact these opportunities. Social actors possessing the relevant cultural knowledge and experience deemed necessary by others to define and exploit a particular opportunity will be able to position themselves as the only ones capable of bringing the opportunity to fruition (Ridgeway et al., 1998; Ridgeway and Erickson, 2000). Thus, social differences will enable some entrepreneurs to achieve "celebrity" status and the possession of distinctive cultural knowledge will represent an important source of competitive advantage (Rindova et al., 2003).

In short, the cultural cognitive school tends to view entrepreneurial opportunities as subjective 
phenomena that are defined and enacted by entrepreneurs through social interaction. Holding all else constant (i.e., What, Where, When, Who, and How), this perspective attributes competitive advantage to discovering and exploiting new interpretations of existing data made possible as a result of shifting preferences (Why). That is, the value of material objects depends on how they are used, which ultimately depends on individuals' wants and needs and how they seek to fulfill them. Thus, changes in interpretations are considered to be the source of entrepreneurial opportunity as emphasis is placed on how strategic issues or "problems" are defined. Concurrently, for all material purposes, the How element is assumed to be constant, such that the novelty of the data is relatively less important than the novel interpretation of the data. The Who element is also held constant by assumption, such that new data or new interpretations are not simply attributed to the involvement of new individuals in the production process.

\subsection{The sociopolitical school}

At the intersection of the economic and cultural cognitive schools is the sociopolitical school. Similar to the economic school, proponents of this perspective emphasize the objective properties of entrepreneurial opportunities. Opportunities tend to be considered objective because they exist in complex webs of social relationships that regulate economic action (Granovetter, 1985). The sociopolitical school sharply departs from economics, however, in its emphasis on network, rather than material, resources (Aldrich and Fiol, 1994; Thornton, 1999). The view also differs from economics in its emphasis on the political processes that are brought to bear to seize entrepreneurial opportunities (Fligstein, 1996, 2002). Thus, opportunities, according to the sociopolitical school, exist objectively in terms of network structures, but social actors must mobilize network resources to exploit them.

By determining patterns of social relations, networks define the types of structural opportunities available to actors. In this sense, network positions play a pivotal role in enabling social actors to discover opportunities (Burt, 1992). Moreover, the location of a given social actor in a particular network determines the critical resources and information that the actor can muster to exploit the opportunities (Burt, 1992). Thus, the network defines the opportunity and the actor's ability to perceive and exploit it.

Governance mechanisms are also extremely important in the discovery and exploitation of entrepreneurial opportunities because they regulate the relations among actors in a given social network. Governance mechanisms, in this view, represent the "rules of the game" and thus refer to the social norms that regulate the behavior of individual participants (DiMaggio and Powell, 1983) as well as the coercive rules that are imposed by outside regulatory entities (Campbell et al., 1991). As a result of their regulatory properties, governance mechanisms determine the degree to which actors are enabled or constrained in their attempts to engage in social action (DiMaggio and Powell, 1983; Giddens, 1984). Given the existence of governance mechanisms, actors must always balance their desire to innovate with the pressures to conform in a given social order (Ruef, 2002).

Faced with these constraints, the entrepreneur must not only recognize entrepreneurial opportunities but also mobilize and organize others to exploit these opportunities successfully (Simpson and Macy, 2001). This task requires the entrepreneur to act with significant political skill by processing disparate sources of information and by forming coalitions and alliances to mobilize resources (Banfield, 1961; Burt, 1992). To this end, entrepreneurs use rhetorical tools and symbols such as narratives to persuade others into accepting their particular representation of a perceived opportunity (Lounsbury and Glynn, 2001). Through these instruments, entrepreneurs leverage their particular ideological frames to imbue opportunities with subjective meaning (Snow et al., 1986). If persuasive, entrepreneurs can mobilize large coalitions to change the rules of the game to their advantage (Aldrich, 1999; Fligstein, 2002). Changes to prevailing governance mechanisms in turn alter the structure and value of entrepreneurial opportunities. As a result, the ability to alter governance mechanisms via resource 
mobilization becomes an important source of competitive advantage.

In short, the sociopolitical school tends to view entrepreneurial opportunities as objective phenomena embedded in network structures. Opportunities, however, acquire subjective meaning when entrepreneurs leverage ideological frames and mobilize people and resources. Holding all else constant (i.e., What, Where, When, Why, and How), this perspective attributes competitive advantage to discovering and exploiting new data or new interpretations of existing data made possible as a result of the involvement of new individuals or increased involvement of existing individuals in the production process (Who). Because this perspective includes changes in data and/or interpretation, it is easy to confuse it with the economic school or the cultural cognitive school. However, those schools emphasized either how something was being produced or why it was being produced and provided less attention to who was and who was not involved in that process. In contrast, the socio-cultural perspective views individuals as possessors of knowledge in the form of both a stock (i.e., objective data) and a flow (i.e., subjective interpretation or meaning making). Thus, who is involved in the production process and to what extent is important because it is likely to impact not only the data that can be drawn upon in decision making (in terms of the quantity of facts) but also how it is interpreted or understood. Therefore, emphasis of this perspective is on the boundaries of the group - who is within the social system and who is outside of it, be it a coalition, alliance, organization, economy, etc. Meanwhile, data (How) and interpretations of data (Why) within the current composition of the social system are implicitly assumed to be relatively constant as change in either is attributed primarily to changes in the composition of the group.

\section{A preliminary typology of entrepreneurial opportunities}

Although scholars have begun to shed light on the sources and nature of entrepreneurial opportunities, they have done little work in identifying and classifying types of entrepre- neurial opportunities. Nevertheless, one can employ the distinctive frameworks of the emerging economic, cultural cognitive, and sociopolitical schools to provide a preliminary classification. Correspondingly, we classify the different types of entrepreneurial opportunities as economic, cultural cognitive, and sociopolitical opportunities. Several subtypes within these categories can also be identified depending on whether the perspective addresses the supply or demand side of a particular production function. Economic opportunities encompass technological and market opportunities resulting from material innovation. Cultural cognitive opportunities consist of cultural innovations introduced into the marketplace by either producers or consumers. Finally, sociopolitical opportunities include network opportunities resulting from the structural features of social networks and political opportunities attributable to changes in the governance structures of these networks. We discuss the various types and subtypes in greater detail below and summarize the preliminary typology in Table I.

\subsection{Economic opportunities}

Economic opportunities can be defined as objective situations that entail material resources and information in the discovery of new value creating, means-ends relationships. They exist as a result of the underlying distribution of information in society (Arrow, 1962). Economic opportunities include both the technological opportunities that make the creation of new goods and services possible, as well as the market opportunities that enable these new goods and services to be commercialized for wealth creation. The former refers to the supply side of technological opportunities, while the latter refers to the demand side of these opportunities. Not only do firms need to combine information, resources, and capabilities in new ways to uncover technological opportunities, but also they need to combine these technological opportunities with latent market needs to discover new market opportunities. As a result, both technological and market opportunities are inextricably related in the value creation process (Gatignon and Xuereb, 1997). 


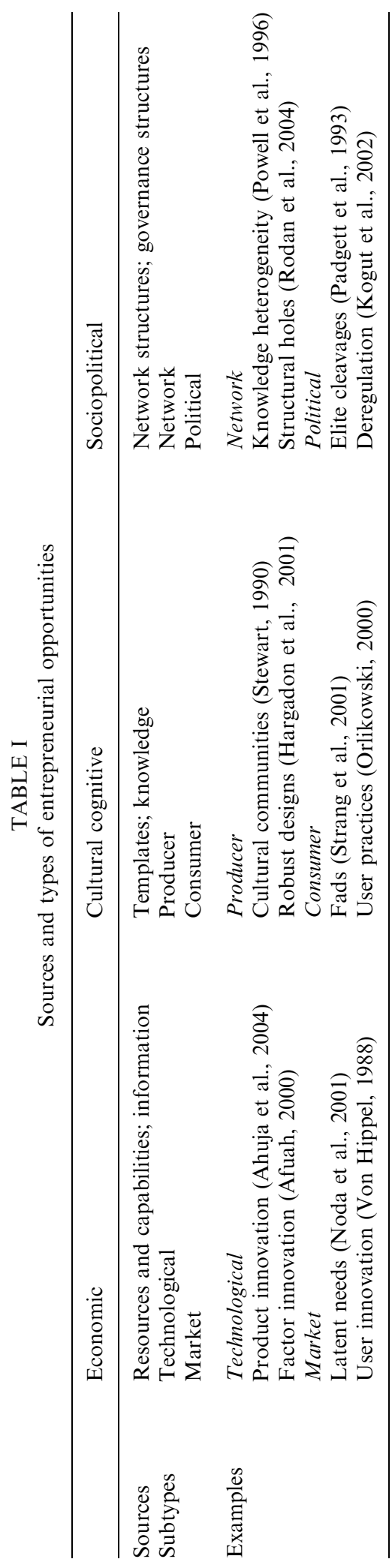

Technological opportunities exist in the form of product innovations (Henderson and Clark, 1990; Ahuja and Katila, 2004), strategic factor innovations (Barney, 1986), and general advancements in technical information (Shane and Venkataraman, 2000; David and Foray, 2003). In an early study of technological change, Tushman and Anderson (1986) found that breakthrough product innovations served as technical discontinuities in existing trajectories that increased environmental uncertainty and served to enhance the competence of new firms at the expense of established firms. The findings were supported by evidence from the minicomputer, cement, and airline industries from their births through 1980. In the study, firms that successfully achieved breakthrough innovation grew faster than firms capitalizing on incremental technological change.

Over the years, other studies have provided further evidence to the importance of breakthrough product innovation as a technological opportunity (e.g., Henderson and Clark, 1990; Henderson and Cockburn, 1994; Christensen and Bower, 1996). Henderson and Cockburn (1994), in particular, showed that the degree of technological opportunity can vary across technology classes. Building on this insight, Ahuja and Katila (2004) employed patent data to construct a measure for technological opportunity based on various technology classes in the US chemical industry. Although the focus of their study was to examine the effects of scientific and geographic search on firm innovation, the study also illustrated that technological opportunity is significantly correlated with breakthrough innovation. The magnitude of the correlation, however, was small. In the study, the authors also found that firms were more likely to reap the benefits of breakthrough innovation when they searched beyond existing technological classes and domestic geographic boundaries to tap into new technological and market opportunities.

Strategic factor innovation, or innovation affecting existing raw materials, represents another type of technological opportunity (Barney, 1986; Afuah, 2000). In a study of the adoption of Reduced Instruction Set Computer (RISC) technology by computer workstation 
makers, Afuah (2000) found that leading firms often lost their competitive advantage when new technological opportunities in strategic factor markets rendered the capabilities of key suppliers obsolete. The finding is important because it highlighted the role of strategic factor innovation as a critical technological opportunity for firms operating along a given supply chain.

Market opportunities represent another important form of economic opportunity. Although technological opportunities result from the pace and speed of technical change, market opportunities emerge through the discovery of hitherto unknown latent consumer needs (Slater and Narver, 1998) or lead user innovations (Von Hippel, 1988). Numerous studies have documented the importance of initial sets of users for entrepreneurial firms in the development of new product innovations (e.g., Holbrook et al., 2000; Noda and Collis, 2001). In a longitudinal study of the development of the US cellular telephone industry, for example, Noda and Collis (2001) found that latent consumer needs represented a new market opportunity for the recently deregulated firms. Following the break up of AT\&T Bell, firms inheriting an initial user base in driving and service intensive markets were quickly able to discover and exploit early cellular opportunities. Over time, however, the expansion of the same initial user base precluded these early movers from identifying emerging opportunities elsewhere as they became trapped in existing market and technological trajectories.

\subsection{Cultural cognitive opportunities}

Cultural cognitive opportunities are subjective situations that require interpretive processes for the enactment of valuable, new means-ends relationships. As entrepreneurs engage in the recombination of existing beliefs and practices, they develop new cultural schemas for interpreting the world. These cultural innovations are then used to enact entrepreneurial opportunities as new social and economic realities. In this vein, one can classify cultural cognitive opportunities according to their source in the value chain: producer opportunities and consumer opportunities. The former refers to the supply side of cultural cognitive opportunities, while the latter refers to the demand side of these opportunities.

Producer opportunities for cultural innovation include the introduction of robust designs by entrepreneurs (Hargadon and Douglas, 2001) and their participation and interaction with others in cultural communities (Stewart, 1990; Brown and Duguid, 1991). In a study of the development of Edison's system of electric lighting, for example, Hargadon and Douglas (2001) found that product innovations are not just technological artifacts. Instead, product innovations are embedded in complex systems of meaning without which they cannot be successfully introduced to and accepted by consumers in existing cultural communities. In this sense, Hargadon and Douglas suggest that innovations are most likely to be successful when their design invokes familiarity in the cultural understandings of a community of interest but at the same time retains the flexibility to evolve beyond these initial understandings to construct new ones.

For new understandings to be developed between producers and consumers, however, consumer opportunities for innovation also need to develop within cultural communities. As such, consumer opportunities are another type of cultural cognitive opportunity. Consumer opportunities include cultural innovations initiated by consumers that attach value to new and existing goods and services. For example, cultural fads (Strang and Macy, 2001) are a consumer opportunity that creates new beliefs about the value of existing goods and services.

A more complex example arises when a new technology is introduced and users need to develop new cultural meanings and practices to facilitate their use (Barley, 1986). Unlike user innovation in the economic sense, the technology's value in such a situation is provided not by material properties but rather by the cultural meanings that users have developed and attached to it (Orlikowski, 2000). The study by Orlikowski (2000) on the introduction and adaptation of the Notes software program illustrates the point. She found that the cultural meanings that gave value to the technology were not embodied within the technology itself but 
rather evolved from the ongoing and situated interactions users had with the technology. Thus, changes in user practices are another example of a consumer opportunity.

\subsection{Sociopolitical opportunities}

Sociopolitical opportunities are objective situations embedded in existing social structures that actors exploit to create new means-ends relationships. Although sociopolitical opportunities most often manifest themselves as network structures, they may also emerge through the mobilization and reconfiguration of network resources given a shifting sociopolitical landscape. In this sense, one can distinguish between network opportunities and political opportunities. These two subtypes serve as a useful starting point for classifying sociopolitical opportunities.

Network opportunities are those resulting from existing social relations in prevailing network structures. Similar to economic opportunities, network opportunities are viewed as objective situations that require discovery and exploitation by alert entrepreneurs. One example of a network opportunity is the presence of knowledge heterogeneity. Heterogeneous knowledge refers to the variety of knowledge, information, and expertise available to social actors through their participation in a particular social network (Rodan and Galunic, 2004). Heterogeneous knowledge is a form of network opportunity because actors can recombine this knowledge to discover and exploit new valued means-ends relationships (Powell et al., 1996).

Another example of a network opportunity is the presence of structural holes or disconnections between a firm's partners (Burt, 1992). Entrepreneurs can capitalize on structural holes by mediating between disconnected actors (Burt, 1992) and sometimes even by translating between distinct spheres of exchange to achieve breakthrough innovation (Stewart, 1990). Structural holes are examples of network opportunities embedded in network structures.

In some cases, simply having access to a given social network may in and of itself represent a form of network opportunity (Powell et al., 1996). In a longitudinal study of 225 indepen- dent firms in the biotechnology industry, Powell et al. (1996) examined the relationship between knowledge structure and innovation in an evolving collaboration network. The authors found that diverse sources of knowledge and experience resulting from network participation enabled biotechnology firms to achieve breakthrough innovation. Early network participants, in turn, were able to establish themselves as central actors as the network grew over time. In this case, the evolving network represented a form of network opportunity to its participants.

In another example, Rodan and Galunic (2004) explored the relationship between structural holes, knowledge heterogeneity, and innovation performance in a study of 106 middle level managers in a European telecommunications firm. The authors found that the presence of heterogeneous knowledge augmented the positive impact of structural holes on innovation performance. Although the study did not address entrepreneurial innovation directly, the findings are nonetheless illustrative of the value of knowledge heterogeneity and structural holes as examples of network opportunities.

As opposed to network opportunities, political opportunities are more intriguing because they require that network participants leverage different ideological frames to interpret and act upon perceived opportunities in the sociopolitical landscape. Although the changes are often provoked by exogenous events such as wars (Scheiber, 1969), deregulation (Kogut and Spicer, 2002), and elite cleavages (Padgett and Ansell, 1993), the events result in changes to prevailing governance mechanisms that are subject to the interpretation and actions of network participants. These exogenous events generate considerable uncertainty, reconfigure the structure of network relations, and permanently alter the institutional governance mechanisms that regulate social action.

In a study of the Florentine banking industry, Padgett and Ansell (1993) explored how the Medici family was able to establish and sustain their dominance in 15 th century Florence. They observed that seemingly dominant network structures fragmented and dissipated during periods of intense sociopolitical change, such as 
wars and revolutions. These exogenous events enabled the Medici family to engage in skillful political bargaining and coalition building to alter the governance mechanisms of the industry to their advantage. In this way, the Medici family successfully changed the rules of the game to create new valuable means-ends relationships.

\section{Strategies for opportunity discovery, exploitation, and wealth creation}

As the previous sections have demonstrated, scholars have developed three distinctive views economic, cultural cognitive, and sociopolitical that have provided different frameworks for conceptualizing and analyzing the sources and types of entrepreneurial opportunities. Surprisingly, strategic management scholars operating within these schools have found common ground on the appropriateness of entrepreneurial strategies in fast changing markets. Entrepreneurial strategy refers to a course of action that firms apply to adapt to "environmental change and exploit opportunities created by uncertainties and discontinuities in the creation of wealth" (Hitt et al., 2001). Following this definition, scholars have argued that entrepreneurial strategies and structures are ideally suited for discovering and exploiting entrepreneurial opportunities when the speed and pace of environmental variability is high. Environmental variability refers to the degree of uncertainty (or ambiguity) and competitive intensity that a particular firm faces in any given market context (Hannan and Freeman, 1984; D'Aveni, 1994; Brown and Eisenhardt, 1997). Thus, entrepreneurial strategies are considered to have a stra- tegic fit with the environment because of its high uncertainty and intense competition.

Despite reaching consensus on the contingent nature of entrepreneurial strategy, structure, and performance, the three perspectives have disagreed on the strategic actions to pursue given the nature of entrepreneurial opportunities. Scholars who contend that entrepreneurial opportunities are objective situations have focused on adaptive strategies that enable entrepreneurial firms to adjust quickly to changing environmental contingencies. In contrast, scholars who view entrepreneurial opportunities as subjective situations have focused on the proactive strategies that enable entrepreneurial firms to define and exploit the shifting landscape rapidly. We explore the logic and implications of these two different strategy categories in this section and summarize the main arguments in Table II.

\subsection{Economic and social strategies for discovering and exploiting objective opportunities}

Strategic management scholars - in particular, resource-based analysts and proponents of strategic alliances - have proposed two types of strategies for exploiting opportunities when they exist objectively in the environment. Resourcebased analysis has proposed an inherently economic strategy that emphasizes the discovery and exploitation of economic opportunities, e.g., new resources and technologies, through resource and capability development. The study of strategic alliances, on the other hand, has proposed an inherently social strategy emphasizing the discovery of network opportunities, e.g., structural holes and heterogeneous

TABLE II

The nature of the opportunity and categories of entrepreneurial strategies

\begin{tabular}{lll}
\hline & Objective & Subjective \\
\hline Source of opportunity & $\begin{array}{c}\text { Resources and capabilities, network } \\
\text { structures } \\
\text { Resource development and networking }\end{array}$ & $\begin{array}{c}\text { Cultural repertoires, governance } \\
\text { structures } \\
\text { Development of templates and } \\
\text { schemas }\end{array}$ \\
$\begin{array}{l}\text { Strategy for opportunity recognition } \\
\begin{array}{l}\text { Source of sustainable competitive } \\
\text { advantage }\end{array}\end{array}$ & $\begin{array}{c}\text { Resource and network reconfiguration } \\
\text { Dynamic capabilities, dynamic ties }\end{array}$ & $\begin{array}{c}\text { Claims making, collective action } \\
\text { Cultural knowledge, political skill }\end{array}$ \\
\hline
\end{tabular}


knowledge, and the exploitation of these opportunities through the reconfiguration of social networks. Collectively, these two types of entrepreneurial strategies enable firms to innovate and generate the network externalities needed to commercialize new goods and services effectively.

Resource-based scholars (Wernerfelt, 1984, 1995; Barney, 1986, 1991; Dierickx and Cool, 1989; Peteraf, 1993) have long studied how firms process information, resources, and capabilities to achieve competitive advantage. They argue that firms are founded with certain resources, capabilities, and technologies (or resource endowments). Over time, firms specialize by investing in the complementary resources and technologies needed to develop a unique resource positioning in the marketplace. The unique configuration in turn enables firms to serve their customers by capitalizing on their comparative advantage vis-à-vis other firms. In doing so, firms establish a competitive advantage while achieving strategic fit with their environment. Thus, the value and uniqueness of a firm's resource configuration becomes the source of competitive advantage.

Emphasis on the firm's resources and technologies given a particular market context, however, has created a static view of wealth creation (Teece et al., 1997). Resource development enables firms to acquire the core competencies needed to serve a given market segment, but what guarantee do these firms have that they will be able to sustain their competitive advantage as market conditions change? More recently, scholars have tried to address this gap by advocating a more dynamic view of resourcebased analysis.

The dynamic capabilities view (Teece et al., 1997; Eisenhardt and Martin, 2000) has complemented resource-based analysis by emphasizing the role that strategic processes play in sustaining competitive advantage in rapidly changing markets. In this view, the knowledge base of a firm can serve as a dynamic capability that enables a firm to process large amounts of heterogeneous information (Grant, 1996). This capability, in turn, can be leveraged to uncover latent market needs and to determine the necessary resources and technologies needed to satisfy those needs. Examples of knowledgebased, dynamic capabilities include the absorptive (Cohen and Levinthal, 1990) and transformative capacity (Garud and Nayyar, 1994) that firms have to process information, learn from previous innovation, and achieve future breakthrough innovation. In addition, they include the low cost probes that firms use to determine the viability of product prototypes by experimenting with and gaining an understanding of user needs in isolated test markets (Brown and Eisenhardt, 1997).

Cohen and Levinthal (1990) provided one early empirical example illustrating how dynamic capabilities enable firms to discover new entrepreneurial opportunities. The authors explored how R\&D knowledge base enables a firm to recognize the value of new external information, assimilate that information, and apply it to the discovery of novel technological opportunities. This ability was labeled as the absorptive capacity of a firm. In a study of the relationship between prior $\mathrm{R} \& \mathrm{D}$ investments and innovation of 151 US manufacturing firms, Cohen and Levinthal found that the two measures were highly correlated. The results suggest that absorptive capacity is a pivotal dynamic capability in the discovery of entrepreneurial opportunities.

Firms can also leverage their dynamic capabilities to exploit entrepreneurial opportunities. In this regard, proponents of the dynamic capabilities view have argued that the degree of uncertainty and competitive intensity that characterize today's high velocity environments make resource development alone insufficient for sustaining competitive advantage. Instead, organic processes that continually refresh a firm's strategy and structure towards the discovery and exploitation of entrepreneurial opportunities are needed to achieve superior performance (Burns and Stalker, 1961; Rindova and Kotha, 2001).

For example, Brown and Eisenhardt (1997) studied the factors that enable high technology firms to commercialize breakthrough innovations. They found that simple rules (or "semi structures") prioritize attention on the critical tasks needed to exploit emerging opportunities while enabling the firm to remain flexible as 
these opportunities change. Similarly, other studies have shown that strategies such as time pacing, whereby a firm creates rhythmic time cycles for opportunity recognition and exploitation, are valuable for achieving breakthrough innovation and superior performance (Gersick, 1994). More generally, strategic processes can be organized and loosely structured in entrepreneurial firms, allowing these firms to act like highly adaptive, organizing communities (Galunic and Eisenhardt, 1996, 2001). In these ways, the strategic processes that sustain organizational structure represent an important source of competitive advantage.

The study by Rindova and Kotha (2001) on the emergence of Internet search engines is a prime example of how dynamic capabilities can be employed to exploit entrepreneurial opportunities. The authors found that Yahoo! and Excite engaged in a process of continuous morphing to migrate quickly into new strategic and competitive domains as market opportunities changed. Continuous morphing, in this context, refers to the processes by which firms reconfigure their resources and capabilities, product and service offerings, and organizational structures to achieve superior performance. In the study, both firms originated as providers of search functions to users of the World Wide Web. Between 1995 and 1998, however, they morphed into content providers and then into interactive service providers. By maintaining fluid structures and processes to identify and exploit emerging market opportunities, these firms transformed themselves continuously to sustain their transient competitive advantage.

Beyond economic strategies, entrepreneurs also employ strategies such as social networking to recognize and exploit entrepreneurial opportunities. As discussed in the previous section, entrepreneurial firms join social networks and enter into strategic alliances to garner the critical resources needed to achieve successful innovation and superior performance (Powell et al., 1996). By participating in a network, for example, an entrepreneurial firm can tap into the heterogeneous sources of knowledge that are pivotal for innovation (Rodan and Galunic, 2004). They can also share information and collaborate in the joint production of goods and services (Piore and Sabel, 1984; Uzzi, 1996). Alternatively, they may discover valuable structural holes that they can exploit to create value or decide to forego these opportunities in the interest of maintaining trust with valued network partners (Ahuja, 2000). In these ways, network embeddedness is critical for entrepreneurial discovery and strategic action.

In a longitudinal study of 23 New York apparel firms, Uzzi (1996) explored how social ties affect innovation and performance. He found that the network provided access to resources and information needed by firms to innovate and adapt to the rapidly changing industry context. For instance, embedded firms worked together to develop joint problem-solving agreements. Joint collaboration resulted in the sharing of tacit knowledge, which accelerated learning and enabled firms to capitalize quickly on emerging market opportunities. The degree of network embeddedness was also found to be associated with a lower probability of failure. In short, Uzzi found that firms embedded in networks of exchange achieve superior performance as a result of interfirm resource pooling, coordination, and adaptation.

Recently, strategic management scholars have also begun to examine the processes by which firms reconfigure existing ties to exploit entrepreneurial opportunities (Gulati and Gargiulo, 1999; Hite and Hesterly, 2001). In a study of 166 US, European, and Japanese industrial firms, Gulati and Gargiulo (1999) explored the processes that drove strategic alliance formation and reconfiguration. The authors posited that experience with network partners today influences the formation of network ties with current partners and new ones in the future. The authors found that the accumulation of network ties serves as a repository of information on potential partners, helping organizations to decide with whom to form new alliances. This process works through structural differentiation. The greater the differentiation of network structures, the greater the value of the information for firms to make future decisions. Over time, the information enables firms to determine the partners with whom to build ties to obtain the complementary resources and capabilities needed to sustain superior performance. 
In summary, the economic school and the sociopolitical school share an understanding of entrepreneurial opportunities as objective situations to the extent that both perspectives view opportunities as originating from changes in data about how to solve existing problems. Whereas the economic view ascribes this change in data primarily to organic development of a firm's resources and capabilities, the sociopolitical view attributes it primarily to the formation of alliances and the development of networks. Regardless of whether it is independent or social in nature, however, the strategy remains the same - enhance one's ability to solve problems by acquiring more information or developing one's ability to acquire more information.

\subsection{Cultural and political strategies for discovering and exploiting subjective opportunities}

Other scholars have focused on the role played by beliefs, values, and ideologies in shaping entrepreneurial action. According to this view, social actors employ a wide range of strategic repertoires to interact and transact with others in the environment (Swidler, 1986). Strategic repertoires consist of the habits, skills, and templates for action considered most efficacious and legitimate for goal attainment (Swidler, 1986). Scholars contend that strategic repertoires provide the resources that social actors need to undertake action in stable market contexts (Swidler, 1986).

In highly ambiguous market contexts, however, actors are unable to make sense of their surroundings and causal ambiguity prevents them from employing strategic repertoires in a straightforward fashion (Weick, 1993). Under these conditions, entrepreneurs seek to reduce uncertainty by developing new schemas and templates that enable them to interpret and define the environment, thereby subjectively defining opportunities for entrepreneurial action (Porac and Thomas, 1990; Fligstein, 1996). To this end, entrepreneurs employ symbols and rhetoric to make persuasive claims to these opportunities (Rindova and Fombrun, 2001; Santos, 2003). At the same time, they act with considerable political skill to convince others of the value of the opportunity and persuade them to join their cause (Rindova and Fombrun,
2001; Santos, 2003). In this regard, entrepreneurs need to anchor their vision of the opportunity in readily shared and diffused beliefs and values (Hargadon and Douglas, 2001).

As discussed earlier in the paper, Hargadon and Douglas (2001) explored how innovations displace existing institutions in the context of the development and adoption of Edison's system of electric lighting. Innovation, in this context, was defined as the process through which entrepreneurs integrate existing cultural beliefs and values to create new understandings, shared meanings, and actions that change the existing social context. The authors found that Edison succeeded at introducing the electric lighting system because he embodied his innovative ideas in designs that were robust enough to exploit the cultural beliefs of the existing social system without being confined by them.

Beyond the constraints of existing values and beliefs, there are also the constraints that governance structures may impose upon entrepreneurial action. In the early stages of opportunity recognition, entrepreneurial action may go undetected at the fringes or interstices of normative and regulatory governance structures as uncertainty over their jurisdiction preclude these structures from adequately regulating over the ambiguous setting (Leblebici et al., 1991; Morrill, 2005). Over time, the value of the opportunity may become apparent and encourage powerful actors to lobby political authorities against the entrepreneur (Leblebici et al., 1991; Fligstein, 1996). In this context, successful exploitation of the opportunity will hinge on the political skill of the entrepreneur to make persuasive claims that call into question the jurisdiction of existing governance mechanisms over the opportunity (Fligstein, 1996). In addition, entrepreneurs will need to bargain skillfully and form coalitions with other, often more powerful, actors to change the governance structures to their advantage (Fligstein, 1996; Rao et al., 2000). At times, they may also be able to employ a strategy of "divide and conquer" by capitalizing on elite cleavages to garner support for their innovative visions of the opportunity (McAdam, 1999).

In a historical case study of the US electrical utility industry, Yakubovich et al., (2005) 
explore how political activities influence the opportunity exploitation process. The authors found that Samuel Insull and his circle of collaborators proposed a system of power generation that was not the most efficient from a technological standpoint. Nevertheless, the group had the wherewithal to recognize that they could leverage their shared understandings and social connections by forming trade associations that would promote their preferred system of self-industry governance. In that highly uncertain market context, Insull and his colleagues institutionalized their preferred template by pressuring competing firms to replace their leadership with Insull subordinates. They also lobbied regulatory agencies to favor the preferred template. Once in control, the group excluded other viable alternative industry models and pressured the emerging industry towards cultural, normative, and regulatory conformity.

In a similar vein, Leblebici et al. (1991) explored how cultural and political activities changed the US radio broadcasting industry from inception to maturity. In the early stages of the industry, the properties and ownership of airwaves were ambiguous and radio equipment was an emergent technology. As a result, the definition of the opportunity in terms of prevailing cultural templates was contested. The US Navy, a major innovator in this area, tried to define radio communications as a natural monopoly to obtain the right to regulate the industry for national security purposes. Newspapers, who owned the first private stations, opposed public control and instead tried to define the opportunity as a free speech issue (e.g., "the newspaper of the air"). Ultimately, the federal government resolved the controversy by using a transportation model to define the opportunity. Leblebici and colleagues also explained that fringe players were generally responsible for the introduction of the economic practices that ultimately defined and transformed the relations between broadcasting stations and listeners throughout the industry's evolution. The authors labeled these actors as "fringe players" because they were less powerful participants whose only possibility to compete with the central players without being sanctioned was to engage in the experimentation of new product and service offerings. Because established players deemed new product and service offerings as radical and tangential to their interests, fringe actors were able to develop these offerings into valuable strategic opportunities in a virtually unnoticed fashion. Once the business models of these fringe players became successful, however, the established players directly appropriated the business models or lobbied political authorities to prevent the erosion of their leadership positions.

In summary, the cultural cognitive school and the sociopolitical school share an understanding of entrepreneurial opportunities as subjective situations to the extent that both perspectives view opportunities as originating from changes in interpretations of an ambiguous environment. Whereas the cultural cognitive school ascribes this change primarily to the development of new schemas and templates, the sociopolitical school attributes it primarily to changes in governance structures that are introduced by fringe actors. Regardless of whether it originates within or outside of the firm, however, the strategy remains the same - redefine the problem by generating superior interpretations of the data.

\subsection{Sources of competitive advantage: integration of objective and subjective opportunities}

Based on the entrepreneurial strategies discussed in this section, the sources of competitive advantage can be summarized according to the nature of the opportunity. The discovery and exploitation of objective opportunities result in superior performance as a result of the material content of economic exchange and the social relations that sustain the production of valued goods and services (Rindova and Fombrun, 1999). In the economic view, dynamic capabilities are the strategic processes by which entrepreneurial firms process information and reconfigure resources and capabilities to adapt to rapidly changing environmental contingencies. In the social view, dynamic ties are the mechanism by which firms quickly reconfigure social networks to exploit emerging opportunities. In short, firms can leverage dynamic ties and capabilities to exploit objective opportunities and sustain their competitive advantage in 
fast changing markets (Eisenhardt and Schoonhoven, 1996).

At the same time, the enactment and exploitation of subjective opportunities results in superior performance as a result of the interpretive and symbolic aspects of exchange and the political activities that sustain the production and distribution of new valuable goods and services (Rindova and Fombrun, 1999). In this regard, the cultural and political bases for competitive advantage lie in cultural knowledge and political skill. In highly ambiguous markets, entrepreneurial firms devise new cultural understandings, but these understandings are difficult to replicate because the means-ends relationships that sustain them are highly uncertain. At the same time, the ability to exploit these understandings entails considerable political skill. Entrepreneurs need to resort to political lobbying and persuade others to join coalitions to change the governance structures to their own advantage. Thus, firms leverage both cultural knowledge and political skill to define and exploit subjective opportunities in highly ambiguous markets.

Are the objective and subjective views of entrepreneurial opportunities inimical? Following the lead of Rindova and Fombrun (1999) and Eisenhardt and Schoonhoven (1996), we propose that these views complement and strengthen one another. A material view of entrepreneurial strategies that does not take into account the important role that interpretation plays in the process is as incomplete as a view that ignores the critical role that material resources play in the discovery and exploitation of entrepreneurial opportunities. By integrating both perspectives, we can produce a richer understanding of the appropriate strategies that should be used to discover and exploit entrepreneurial opportunities.

\section{Discussion and conclusion}

In this paper, we sought to explore two questions. First, what do entrepreneurial opportunities look like? And second, how do firms discover and exploit these opportunities to create value and sustain competitive advantage? To answer both questions, we reviewed the strategic management and entrepreneurship literatures to identify the nature and character of entrepreneurial opportunities and the entrepreneurial strategies that firms employ to seize and commercialize these opportunities.

We argued that three distinctive schools are emerging regarding entrepreneurial opportunities, each of which has emphasized a different source of opportunity. The economic school has argued that entrepreneurial opportunities exist as a result of the distribution of information about material resources in society. The cultural cognitive school has argued that entrepreneurial opportunities exist as a result of environmental ambiguity and the cultural resources available to interpret and define these opportunities. Finally, the sociopolitical school has stressed the role of network and political structures in defining entrepreneurial opportunities.

Using Whetten's (1989) conceptual framework of theory development, we demonstrated how these schools tend to emphasize one element (either How, Why, or Who) of opportunities (Where and When) for entrepreneurial action (What) while implicitly assuming that the other elements are constant. As a result, the non-focal elements are left to vary. Given that data, interpretations of data, and the individuals engaged in interpretation of data are all likely to change simultaneously in uncertain and ambiguous environments like those in which entrepreneurial action is often assumed to occur, it would seem that failure to control for these nonfocal elements of entrepreneurial action could allow configural effects to moderate, negate, or even contradict one's theoretical conclusions.

In this respect, the sociopolitical school has enormous potential to serve as a bridge between the economic and cultural cognitive schools as long as the elements of data acquisition and interpretation are not neglected in the sociopolitical school's emphasis of whom is providing the data or its interpretation. By emphasizing the objective nature of network opportunities, the sociopolitical school is consistent with the economic school because similar entrepreneurial strategies can be employed to discover these opportunities. At the same time, the sociopolitical school emphasizes the importance of ideological content in the exploitation of entre- 
preneurial opportunities, making the perspective consistent with the cultural cognitive school. Although some scholars have attempted to integrate these perspectives into a unified theoretical framework (Rindova and Fombrun, 1999), few empirical studies have sought systematically to apply all the perspectives in the study of entrepreneurial opportunities (e.g., Eisenhardt and Schoonhoven, 1996).

By using the emerging schools as a guide, we constructed a preliminary classification of entrepreneurial opportunities. The classification encompasses economic, cultural cognitive, and sociopolitical opportunities. First, economic opportunities are defined as objective situations that entail material resources and information in the discovery of new value creating, means-ends relationships. Second, cultural cognitive opportunities are subjective situations that require interpretive processes for the enactment of valuable, new means-ends relationships. Finally, sociopolitical opportunities are objective situations embedded in existing social structures that actors exploit to create new means-ends relationships. Collectively, these opportunities define the opportunity structure that is available to entrepreneurs in the environment.

We then identified six subtypes of entrepreneurial opportunities based upon supply and demand concerns. Economic opportunities were further classified into the technological opportunities that make the creation of new goods and services possible and the market opportunities that enable these new goods and services to be commercialized for wealth creation. Similarly, cultural cognitive opportunities were further classified according to their source in the value chain: producer opportunities and consumer opportunities. Finally, sociopolitical opportunities were further differentiated into the opportunities that result from prevailing network configurations and structures and the opportunities resulting from exogenous political events or endogenous strategies of collective action and political lobbying.

Afterwards, we reviewed the entrepreneurial strategies that scholars have advocated for entrepreneurs to discover and exploit entrepreneurial opportunities. Scholars have contended that entrepreneurial strategies are contingent on the nature of the opportunity and the degree of environmental variability. In particular, the three schools show remarkable consensus on the premise that entrepreneurial strategies should be employed in rapidly moving markets characterized by high uncertainty and intense competition. In terms of the relationship between strategy, structure, and performance, given the nature of the opportunity, scholars have emphasized economic and social strategies to discover and exploit objective opportunities, and cultural and political strategies to identify and seize subjective ones. In the former case, the roots of sustainable competitive advantage are in dynamic capabilities and dynamic ties. In the latter, the source is cultural knowledge and political skill. Overall, the three perspectives are advancing our understanding of the sources, processes, and outcomes of opportunity recognition and exploitation for achieving superior performance.

\subsection{Directions for future research}

One surprising limitation in the literature is that, although scholars typically employ the opportunity construct, they have yet to develop an integrated theoretical framework that explains the emergence and development of entrepreneurial opportunities. Drawing from Whetten (1989) and a remarkable body of research that employs the opportunity construct effectively but without specification, we sought to outline the beginnings of a typology of entrepreneurial opportunity by making implicit assumptions explicit. In doing so, we believe that there is sufficient literature to construct a taxonomic classification on entrepreneurial opportunities, an endeavor that was beyond the scope of the present paper. Nevertheless, we encourage other scholars to develop such a framework to advance understanding of entrepreneurial opportunities.

Another important limitation in extant research has been that scholars seem to be enamored with contingent arguments of entrepreneurial opportunities. As the paper has shown, scholars have typically defined entrepreneurial opportunities as contingent 
phenomena whose discovery and exploitation depends on the speed and pace of environmental change. Although scholars have recognized that entrepreneurial opportunities exist in the environment (Shane and Venkataraman 2000; Denrell et al., 2003), they seem to be beholden to the notion that opportunities are most relevant and should be exploited under conditions of environmental uncertainty. Such a view, however, ignores the possibility that entrepreneurs deliberately create environmental uncertainty as they discover and exploit new opportunities. By moving away from contingent arguments, scholars could increase the generalizability of their theoretical arguments. In this way, the focus would be on how economic actors purposefully enact new opportunities to create uncertainty in a variety of industry environments, rather than on how they identify and seize opportunities to adapt to fast changing markets.

The emphasis on the relationship between entrepreneurial strategy and environmental contingencies may be related to increased research on high technology industries, as a result of an academic and popular fascination with technological change and the spillovers generated by new technologies. Yet research has shown that entrepreneurship and innovation can create enormous value even in relatively static industry settings (Bhide, 2000). For example, Bhide (2000) was surprised to find that the most common type of successful start up was not a high technology firm but rather an enterprise whose founder leverages prior experience to pursue radical ideas that serve previously untapped market segments. In a separate study, Rindova and Fombrun (2001) showed that, until the emergence of Starbucks, the retail coffee industry had been relatively static with little or no change in the industry for 50 years. The entry of Starbucks revolutionized the coffee industry by increasing uncertainty and intensifying competition. Finally, industrial demographers have shown that the onset of microbreweries increased uncertainty and intensified competition among beer manufacturers long after competitive and institutional processes had stabilized the industry (Carroll and Hannan, 2002).
These empirical examples challenge the conventional view of entrepreneurial firms as adapters in fast moving markets. Although it may be true that firms often adapt to the shifting landscape, we must not assume that these are the only conditions under which entrepreneurship occurs nor the only settings where entrepreneurial strategies prove valuable. Instead, scholars should recognize that entrepreneurial firms are not only adaptive but also often the source of the increased uncertainty and competition that scholars observe in the environment. There is an important duality here: uncertainty may not only open up new opportunities, but new opportunities may also create considerable uncertainty. In this sense, we should also see entrepreneurs typically employing strategies that "shake up" existing industries and markets and sometimes even lead to the creation of new ones. In sum, scholars need to develop an integrated perspective of entrepreneurial opportunities that emphasizes the creation of uncertainty as a strategy that induces environmental variability and not just view uncertainty as an outcome of that variability. As a corollary, scholars should also conduct more empirical research on how entrepreneurs discover and exploit opportunities to transform static industries and markets.

In addition, scholars need to conduct more research on the supply and demand of opportunities. Opportunities for whom and for what is an important question to ask here (Shane and Venkataraman, 2000). Typically, scholars conceptualize opportunity discovery and exploitation as a linear process of value creation from producers to consumers. There are instances, however, when the process is non-linear. For example, consumers may act as the agents of discovery and, as a result of their discoveries, become the producers who exploit entrepreneurial opportunities. This phenomenon is particularly common in open source networks, where user innovation often leads to the production of new methods (Von Hippel, 1986; O’Mahony, 2002). Moreover, institutionalized actors exist whose role it is to discover and exploit opportunities for other firms. For example, IDEO is well known for 
helping nascent and established companies to achieve breakthrough design innovations (Hargadon and Sutton, 1997; Taylor, 2004). We still do not have a good understanding of the role of these firms in the processes of opportunity discovery and exploitation. In this context, scholars need a more sophisticated framework for conceptualizing the production and consumption of entrepreneurial opportunities.

Finally, more research is needed across levels of analysis and geographic settings. Entrepreneurial opportunities for innovation exist at the individual, firm, and industry levels. Moreover, individuals and firms are enabled and constrained in different ways to seize opportunities. In addition, the spillovers resulting from these processes may result in positive and negative feedback across multiple levels of analysis and geographies. Further research into these areas will enable scholars to develop a more fine grained view of the nature and character of entrepreneurial opportunities as well as the strategies and tactics that should be employed to discover and exploit these opportunities for wealth creation.

In conclusion, we hope to have demonstrated not only that entrepreneurial opportunities are situations that enable the introduction of new goods and services but also that strategies to discover and exploit them depend on the element of action that is deemed responsible for creating the opportunity by changing the current situation. If the origin of entrepreneurial opportunity is thought to be changes in data, then opportunities tend to be viewed as objective phenomena that firms discover and exploit by acquiring more information through dynamic capabilities or dynamic ties. However, if the origin of entrepreneurial opportunity is thought to be changes in interpretation, then opportunities tend to be viewed as subjective phenomena that firms discover and exploit by devising new understandings through cultural knowledge and political skill. Finally, we hope to have shown that both schools of thought and a typology of entrepreneurial opportunity have emerged from the literature as a result of scholars emphasizing one element of action to the relative neglect of others. By recognizing that research on opportunities for entrepreneurial action requires that each element be addressed explicitly, we believe that entrepreneurship and strategy scholars will be able to avoid misleading conclusions that may otherwise occur as a result of configural effects.

\section{Acknowledgements}

This paper greatly benefited from discussions with colleagues at the Max Planck Institute; the Stanford Technology Ventures Program; the Stanford Center for Work, Technology and Organization; and the Economic Sociology Research Group at Stanford University. We also gratefully acknowledge the insights of Zoltan Acs, Howard Aldrich, David Audretsch, Stephen Barley, Kathy Eisenhardt, Neil Fligstein, Mark Granovetter, Riitta Katila, Frederick Lehmann, Peter Murmann, Larry Plummer, Violina Rindova, Carlos RodriguezLluesma and Bob Sutton during the development of this project. Any errors are the sole responsibility of the authors.

\section{References}

Afuah, A., 2000, 'How Much Do Your Co-opetitors' Capabilities Matter in the Face of Technological Change?', Strategic Management Journal 21(3), 387-404.

Ahuja, G., 2000, 'Collaboration Networks, Structural Holes, and Innovation: A Longitudinal Study', Administrative Science Quarterly 45(3), 425-455.

Ahuja, G. and R. Katila, 2004, 'Where Do Resources Come From? The Role of Idiosyncratic Situations', Strategic Management Journal 25, 887-904.

Ahuja, G. and C. Lampert, 2001, 'Entrepreneurship in the Large Corporation: A Longitudinal Study of How Established Firms Create Breakthrough Inventions', Strategic Management Journal 22(6/7), 521-543.

Aldrich, H. E., 1999, Organizations Evolving, Thousand Oaks, CA: Sage Publications.

Aldrich, H. E. and C. M. Fiol, 1994, 'Fools Rush In? The Institutional Context of Industry Creation', Academy of Management Review 19(4), 645-670.

Arrow, K. J., 1962, Economic Welfare and the Allocation of Resources for Invention, in R. Nelson. (ed.), The Rate and Direction of Inventive Activity, Princeton, NJ: Princeton University Press.

Banfield, E., 1961, Political Influence, Glencoe, IL: Free Press. 
Barley, S. R., 1986, 'Technology as an Occasion for Structuring: Evidence from Observations of CT Scanners and the Social Order of Radiology Departments', Administrative Science Quarterley 31(1), 78-108.

Barney, J., 1991, 'Firm Resources and Sustained Competitive Advantage', Journal of Management 17(1), 99-120.

Barney, J. B., 1986, 'Strategic Factor Markets: Expectations, Luck, and Business Strategy', Management Science 32(10), 1231-1241.

Bhide, A. V., 2000, The Origins and Evolution of New Businesses, Oxford, UK: Oxford University Press.

Brown, J. S. and P. Duguid, 1991, 'Organizational Learning and Communities of Practice: Toward a Unified View of Working, Learning, and Innovation', Organization Science 2(1), 40-57.

Brown, S. L. and K. M. Eisenhardt, 1997, 'The Art of Continuous Change: Linking Complexity Theory and TimePaced Evolution in Relentlessly Shifting Organizations', Administrative Science Quarterly 42(1), 1-34.

Burns, T. and G. M. Stalker, 1961, The Management of Innovation, London: Tavistock.

Burt, R., 1992, Structural Holes: The Social Structure of Competition, Cambridge, MA: Harvard University Press.

Campbell, J. L., J. R. Hollingsworth and L. N. Lindberg, 1991, Governance of the American Economy, New York, NY: Cambridge University Press.

Carroll, G. R. and M. T. Hannan, 2002, The Demography of Corporations and Industries, Princeton, NJ: Princeton University Press.

Casson, M., 1982, The Entrepreneur: An Economic Theory, Totowa, NJ: Barnes \& Noble Books.

Casson, M., 2003, The Entrepreneur, New York, NY: Edward Elgar Publishing.

Christensen, C. M. and J. L. Bower, 1996, 'Customer Power, Strategic Investment, and the Failure of Leading Firms', Strategic Management Journal 17(3), 197-218.

Cohen, W. M. and D. A. Levinthal, 1990, 'Absorptive Capacity: A New Perspective on Learning and Innovation', Administrative Science Quarterly 35(1), 128-152.

D'Aveni, R. A., 1994, Hypercompetition: Managing the Dynamics of Strategic Maneuvering, New York: The Free Press.

David, P. A. and D. Foray, 2003, 'Economic Fundamentals of the Knowledge Society', Policy Futures in Education 1, 1.

Denrell, J., C Fang and S. G. Winter, 2003, 'The Economics of Strategic Opportunity', Strategic Management Journal 24, 977-990.

Dierickx, I. and K. Cool, 1989, 'Asset Stock Accumulation and Sustainability of Competitive Advantage', Management Science 35(12), 1504-1511.

DiMaggio, P. J. and W. W. Powell, 1983, 'The Iron Cage Revisited: Institutional Isomorphism and Collective Rationality in Organizational Fields', American Sociological Review 48, 147-160.

Eisenhardt, K. M. and C. B. Schoonhoven, 1990, 'Organizational Growth: Linking Founding Team, Strategy, Environment, and Growth Among U. S. Semiconductor Ventures, 1978-1988', Administrative Science Quarterly 35(3), 504-529.
Eisenhardt, K. M. and J. A. Martin, 2000, 'Dynamic Capabilities: What Are They?', Strategic Management Journal 21(10/11), 1105-1121.

Eisenhardt, K. M. and C. B. Schoonhoven, 1996, 'ResourceBased View of Strategic Alliance Formation: Strategic and Social Effects in Entrepreneurial Firms', Organization Science 7(2), 136-150.

Fligstein, N., 1996, 'Markets as Politics: A Political-Cultural Approach to Market Institutions', American Sociological Review 61(4), 656-673.

Fligstein, N., 2002, The Architecture of Markets: An Economic Sociology of Twenty-First Century Capitalist Societies, Princeton, NJ: Princeton University Press.

Galunic, D. C. and K. M. Eisenhardt, 1996, 'The Evolution of Intracorporate Domains: Divisional Charter Losses in High-Technology, Multidivisional Corporations', Organization Science 7(3), 255-282.

Galunic, D. C. and K. M. Eisenhardt, 2001, 'Architectural Innovation and Modular Corporate Forms', Academy of Management Journal 44(6), 1229-1250.

Garud, R. and P. R. Nayyar, 1994, 'Transformative Capacity: Continual Structuring by Intertemporal Technology Transfer', Strategic Management Journal 15(5), 365-385.

Gatignon, H. and J. Xuereb, 1997, 'Strategic Orientation of the Firm and New Product Performance', Journal of Marketing Research 34(1), 77-90.

Gersick, C. J. G., 1994, 'Pacing Strategic Change: The Case of a New Venture', Academy of Management Journal 37(1), 9-45.

Giddens, A., 1984, The Constitution of Society, Berkeley, CA: University of California Press.

Granovetter, M., 1985, 'Economic Action and Social Structure: The Problem of Embeddedness', American Journal of Sociology 91, 481-510.

Grant, R. M., 1996, 'Toward a Knowledge-Based Theory of the Firm', Strategic Management Journal 17(10), 109-122.

Gulati, R. and M. Gargiulo, 1999, 'Where Do Interorganizational Networks Come From?', American Journal of Sociology 104(5), 1439-1493.

Hannan, M. T. and J. Freeman, 1984, 'Structural Inertia and Organizational Change', American Sociological Review 49(2), 149-164.

Hargadon, A. B. and Y. Douglas, 2001, 'When Innovations Meet Institutions: Edison and the Design of the Electric Light', Administrative Science Quarterly 46, 476-501.

Hargadon, A. and R. I. Sutton, 1997, 'Technology Brokering and Innovation in a Product Development Firm', Administrative Science Quarterly 42(4), 716-749.

Henderson, R. and I. Cockburn, 1994, 'Measuring Competence? Exploring Firm Effects in Pharmaceutical Research', Strategic Management Journal 15, 63-84.

Henderson, R. M. and K. B. Clark, 1990, 'Architectural Innovation: The Reconfiguration of Existing Product Technologies and the Failure of Established Firms', Administrative Science Quarterly 35(1), 9-30.

Hite, J. M. and W. S. Hesterly, 2001, 'The Evolution of Firm Networks: From Emergence to Early Growth of the Firm', Strategic Management Journal 22(3), 275-286.

Hitt, M. A., R. D. Ireland, M. S. Camp and D. L. Sexton, 2001, 'Guest Editors' Special Introduction to the Special Issue on 
Strategic Entrepreneurship: Entrepreneurial Strategies for Wealth Creation', Strategic Management Journal 22, 479491.

Holbrook, D., W. M. Cohen, D. A. Hounshell and S. Klepper, 2000, 'The Nature, Sources, and Consequences of Firm Differences in the Early History of the Semiconductor Industry', Strategic Management Journal 21(10-11), 9971016.

Homans, G. C., 1964, Social Behavior: Its Elementary Forms, New York: Harcourt Brace Jovanovich, Inc.

Jacobson, R., 1992, 'The "Austrian School" of Strategy', The Academy of Management Review 17(4), 782-807.

Jaffe, A. B., 1986, 'Technological Opportunity and Spillovers of R\&D: Evidence from Firms, Patents, Profits, and Market Value', The American Economic Review 76(5), 984-1001.

Kirzner, I. M., 1973, Competition and Entrepreneurship, Chicago, IL: University of Chicago Press.

Kirzner, I. M., 1997, 'Entrepreneurial Discovery and the Competitive Market Process: An Austrian Approach', Journal of Economic Literature 35(1), 60-85.

Kogut, B. and A. Spicer, 2002, 'Capital Market Development and Mass Privatization are Logical Contradictions: Lessons from Russia and the Czech Republic', Industrial and Corporate Change 11(1), 1-36.

Latane, B. and J. Darley, 1968, 'Group Inhibition of Bystander Intervention in Emergencies', Journal of Personality \& Social Psychology 10, 215-221.

Leblebici, H., G. R. Salancik, A. Copay and T. King, 1991, 'Institutional Change and the Transformation of Interorganizational Fields: An Organizational History of the U.S. Radio Broadcasting Industry', Administrative Science Quarterley 36, 333-363.

Lieberman, M. B. and D. B. Montgomery, 1988, 'First-Mover Advantages', Strategic Management Journal 9, 41-58.

Lounsbury, M. and M. A. Glynn, 2001, 'Cultural Entrepreneurship: Stories, Legitimacy, and the Acquisition of Resources', Strategic Management Journal 22(6/7), 545-564.

March, J. G., 1991, 'Exploration and Exploitation in Organizational Learning', Organization Science 2(1), 71-87.

March, J. G. and H. A. Simon, 1958, Organizations, New York, NY: McGraw-Hill.

McAdam, D., 1999, Political Process and the Development of Black Insurgency, Chicago, IL: University of Chicago Press.

McMullen, J. S. and D. A. Shepherd, 2006, 'Entrepreneurial Action and the Role of Uncertainty in the Theory of the Entrepreneur', Academy of Management Review 31(1), 132152.

Morrill, C., 2005, Institutional Change Through Interstitial Emergence: The Growth of Alternative Dispute Resolution in American Law, 1965-1995, in W. W. Powell and D. L. Jones (eds.), How Institutions Change, Chicago, IL: University of Chicago Press.

Mosakowski, E., 1997, 'Strategy Making under Causal Ambiguity: Conceptual Issues and Empirical Evidence', Organization Science 8(4), 414-442.

Mosakowski, E., 1998, 'Entrepreneurial Resources, Organizational Choices and Competitive Outcomes', Organization Science 9(6), 625-643.
Nelson, R. R. and S. G. Winter, 1982, An Evolutionary Theory of Economic Change, Cambridge, MA: The Belknap Press.

Noda, T. and D. J. Collis, 2001, 'The Evolution of Intraindustry Firm Heterogeneity: Insights from a Process Study', Academy of Management Journal 44(4), 897-926.

O'Mahony, S. C., 2002, The Emergence of a New Commercial Actor: Community Managed Software Projects. Management Science and Engineering Department, Stanford, CA: Stanford University.

Orlikowski, W. J., 2000, 'Using Technology and Constituting Structures: A Practice Lens for Studying Technology in Organizations', Organization Science 11(4), 404- 428.

Padgett, J. F. and C. K. Ansell, 1993, 'Robust Action and the Rise of the Medici, 1400-1434', American Journal of Sociology 98(6), 1259-1319.

Peteraf, M. A., 1993, 'The Cornerstone of Competitive Advantage: A Resource-Based View', Strategic Management Journal 14, 179-191.

Piore, M. J. and C. F. Sabel, 1984, The Second Industrial Divide: Possibilities for Prosperity, New York, NY: Basic Books.

Porac, J. F. and H. Thomas, 1990, 'Taxonomic Mental Models in Competitor Definition', Academy of Managament Review 15(2), 224-240.

Powell, W. W., K. W. Koput and L. Smith-Doerr, 1996, 'Interorganizational Collaboration and the Locus of Innovation: Networks of Learning in Biotechnology', Administrative Science Quarterly 41(1), 116-145.

Rao, H., C. Morrill and M. N. Zald, 2000, 'Power Plays: How Social Movements and Collective Action Create New Organizational Forms', Research in Organizational Behavior 22, 237-283.

Ridgeway, C. L., E. H. Boyle, K. J. Kuipers and D. T. Robinson, 1998, 'How Do Status Beliefs Develop? The Role of Resources and Interactional Experience', American Sociological Review 63(3), 331-350.

Ridgeway, C. L. and K. G. Erickson, 2000, 'Creating and Spreading Status Beliefs', American Journal of Sociology 106(3), 579-615.

Rindova, V. P. and C. J. Fombrun, 1999, 'Constructing Competitive Advantage: The Role of Firm-Constituent Interactions', Strategic Management Journal 20, 691-710.

Rindova, V. P. and C. J. Fombrun, 2001, ,Entrepreneurial Action in the Creation of the Specialty Coffee Niche', in C. B. Schoonhoven and E. Romanelli (eds.), The Entrepreneurship Dynamic: Origins of Entrepreneurship and the Evolution of Industries. Stanford, CA: Stanford University Press, 236-261.

Rindova, V. P. and S. Kotha, 2001, 'Continuous ,Morphing': Competing Through Dynamic Capabilities, Form and Function', Academy of Management Journal 44(6), 12631280.

Rindova, V. P., T. G. Pollock and M. Hayward, 2003, Celebrity Firms: The Social Construction of Market Popularity, Seattle, WA: Academy of Management Conference.

Roberts, P. W. and K. M. Eisenhardt, 2003, 'Austrian Insights on Strategy: From Market Insights to Implications for Firms', Strategic Organization 1(3), 345-352. 
Rodan, S. and C. Galunic, 2004, 'More Than Network Structure: How Knowledge Heterogeneity Influences Managerial Performance and Innovativeness', Strategic Management Journal 25, 541-562.

Ruef, M., 2002, 'Strong Ties, Weak Ties, and Islands: Structural and Cultural Predictors of Organizational Innovation', Industrial and Corporate Change 11(3), 427-449.

Santos, F. M. 2003, 'Constructing Niches and Shaping Boundaries: Entrepreneurial Action in Nascent Markets', Unpublished Dissertation, Stanford University, Stanford, CA.

Scheiber, H. N., 1969, 'World War I as Entrepreneurial Opportunity: Willard Straight and the American International Corporation', Political Science Quarterly 84(3), 486511.

Scherer, F. M., D. Harhoff and J. Kukies, 2000, 'Uncertainty and the Size Distribution of Rewards from Technological Innovation', Journal of Evolutionary Economics 10(1), 175200.

Schumpeter, J. A., 1934, The Theory of Economic Development, Cambridge, MA: Harvard University Press.

Shane, S., 2000, 'Prior Knowledge and the Discovery of Entrepreneurial Opportunities', Organization Science 11(4), 448-469.

Shane, S., 2001, 'Technology Regimes and New Firm Formation', Management Science 47(9), 1173-1190.

Shane, S. and S. Venkataraman, 2000, 'The Promise of Entrepreneurship as a Field of Research', Academy of Management Review 25(1), 218-228.

Simpson, B. and M. W. Macy, 2001, 'Collective Action and Power Inequality: Coalitions in Exchange Networks', Social Psychology Quarterly 64(1), 88-100.

Slater, S. F. and J. C. Narver, 1998, 'Customer-Led and Market-Oriented: Let's Not Confuse the Two', Strategic Management Journal 19(10), 1001-1006.

Snow, D. A., E. B. Rochford, Jr., S. K. Worden and R. D. Benford, 1986, 'Frame Alignment and Mobilization', American Sociological Review 51(4), 464-481.

Stewart, A., 1990, 'The Bigman Metaphor for Entrepreneurship: A "Library Tale" with Morals on Alternatives for Further Research', Organization Science 1(2), 143-159.
Strang, D. and M. Macy, 2001, 'In Search of Excellence: Fads, Success Stories, and Adaptive Emulation', American Journal of Sociology 107, 147-183.

Swidler, A., 1986, 'Culture in Action: Symbols and Strategies', American Sociological Review 51(2), 273-286.

Taylor, C., 2004, ,Move Over DaVinci: How Design Guru David Kelley Is Bringing Fresh Thinking to Big Business', Time Magazine, A8-A12.

Teece, D. J., G. Pisano and A. Shuen, 1997, 'Dynamic Capabilities and Strategic Management', Strategic Management Journal 18(7), 509-533.

Thornton, P. H., 1999, 'The Sociology of Entrepreneurship', Annual Review of Sociology 25, 19-46.

Tushman, M. L. and P. Anderson, 1986, 'Technological Discontinuities and Organizational Environments', Administrative Science Quarterly 31(3), 439-466.

Uzzi, B., 1996, 'The Sources and Consequences of Embeddedness for the Economic Performance of Organizations: The Network Effect', American Sociological Review 61, 674-698.

Von Hippel, E., 1986, 'Lead Users: A Source of Novel Product Concepts', Management Science 32, 791-805.

Von Hippel, E., 1988, The Sources of Innovation, New York, NY: Oxford University Press.

Weick, K. E., 1979, The Social Psychology of Organizing, Reading, MA: Addison-Wesley.

Weick, K. E., 1993, 'The Collapse of Sensemaking in Organizations: The Mann Gulch Disaster', Administrative Science Quarterly 38, 628-652.

Wernerfelt, B., 1984, 'A Resource-Based View of the Firm', Strategic Management Journal 5(2), 171-180.

Wernerfelt, B., 1995, 'The Resource-Based View of the Firm: Ten Years After', Strategic Management Journal 16(3), 171174.

Whetten, D. A., 1989, 'What Constitutes a Theoretical Contribution?', Academy of Management Review 14(4), 490-495.

Yakubovich, V., M. Granovetter and P. McGuire, 2005, 'Electric Charges: The Social Construction of Rate Systems', Theory \& Society 34(5/6), 579-612. 